\title{
Reformulasi Sanksi Administrasi Bersifat Primum Remedium Dalam Pengelolaan Perikanan (Sebuah Upaya Memberi Efek Jera Bagi Korporasi Pelanggar Ketentuan Di Bidang Perikanan)
}

\author{
Mohamad Rifki \\ Magister Ilmu Hukum Universitas Gadjah Mada, E-mail: m.rifki.bho@gmail.com
}

\begin{abstract}
Law Number 31 of 2004 concerning Fisheries, as amended by Law Number 45 of 2009 (Fisheries Law), has regulated threats of sanction to people and corporation. But, violations committed by corporation are still rampant, because its formulation of criminal sanction can't punish corporation. This research try to analyzing formulation of administrative sanction on Fisheries Law to be primum remedium so that it is expected to have a deterrent effect on the corporation, as well as trying to provide a formulation of the administrative sanctions on the potential violations in the field of fisheries. Based on searches conducted in a judicial normative, it was concluded that to be able to ensnare the corporation so that it have a deterrent effect, need to sort out the threat of administrative sanction that are primum remedium. However, the results of reformulation don't mean eliminating criminal threats at all.
\end{abstract}

Keywords: Fisheries Law, Administrative Sanctions, the deterrent effect of the corporation, reformulation administrative sanctions.

\begin{abstract}
Abstrak
Undang-Undang Nomor 31 Tahun 2004 tentang Perikanan, sebagaimana telah diubah dengan Undang-Undang Nomor 45 Tahun 2009 (UU Perikanan), mengatur ancaman sanksi kepada orang maupun korporasi. Namun, pelanggaran yang dilakukan korporasi masih terjadi, karena rumusan sanksi pidananya tidak dapat menyentuh korporasi. Penelitian ini menganalisis formulasi sanksi administrasi dalam UU Perikanan untuk dapat bersifat primum remedium sehingga diharapkan memberi efek jera bagi korporasi, sekaligus mencoba memberikan reformulasi sanksi administrasi tersebut terhadap potensi pelanggaran di bidang perikanan. Berdasarkan penelusuran yang dilakukan secara yuridis normatif, disimpulkan bahwa untuk dapat menjerat korporasi sehingga memberikan efek jera, perlu memilah kembali ancaman sanksi yang bernuansa administrasi agar dirumuskan bersifat primum remedium. Hanya saja, hasil reformulasi yang dilakukan bukan berarti menghapuskan ancaman pidana sama sekali.
\end{abstract}

Kata Kunci: UU Perikanan, Sanksi Administrasi, Efek Jera Korporasi, Reformulasi Sanksi Administrasi.

\section{Pendahuluan}

Pembentukan Undang-Undang Nomor 31 Tahun 2004 tentang Perikanan, merupakan tindak lanjut amanat konstitusi sebagaimana dimaksud dalam UndangUndang Dasar Negara Republik Indonesia Tahun 1945, bahwa Indonesia memiliki 
kedaulatan dan yurisdiksi atas wilayah perairan Indonesia, serta kewenangan dalam rangka menetapkan ketentuan tentang pemanfaatan sumber daya ikan, baik untuk kegiatan penangkapan maupun pembudidayaan ikan sekaligus meningkatkan kemakmuran dan keadilan guna pemanfaatan yang sebesar-besarnya bagi kepentingan bangsa dan negara dengan tetap memperhatikan prinsip kelestarian sumber daya ikan dan lingkungannya serta kesinambungan pembangunan perikanan nasional. ${ }^{1}$

Hal ini pula yang menjadi dasar pertimbangan filosofis penyusunan UndangUndang Nomor 45 Tahun 2009 tentang Perubahan atas Undang-Undang Nomor 31 Tahun 2004 tentang Perikanan (selanjutnya disebut UU Perikanan), sebagai penyempurnaan pengelolaan perikanan, sebagai berikut²:

"Bahwa perairan yang berada di bawah kedaulatan dan yurisdiksi Negara Kesatuan Republik Indonesia dan Zona Ekonomi Eksklusif Indonesia serta laut lepas berdasarkan ketentuan internasional, mengandung sumber daya ikan dan lahan pembudidayaan ikan yang potensial, merupakan berkah dari Tuhan Yang Maha Esa yang diamanahkan pada Bangsa Indonesia yang memiliki Falsafah Hidup Pancasila dan UUD NRI Tahun 1945, untuk dimanfaatkan sebesar-besarnya bagi kesejahteraan dan kemakmuran rakyat Indonesia."

Perangkat hukum yang dimiliki oleh Indonesia tersebut, sudah cukup maju dengan mengatur korporasi sebagai salah satu subjek hukum. Hanya saja, rumusan dalam UU Perikanan belum terlalu mengeksplor potensi pelanggaran yang dilakukan oleh korporasi atas perizinan yang telah diberikan, dan luput mengancam sanksi atas pelanggaran yang dilakukan oleh korporasi. ${ }^{3}$ UU Perikanan lebih banyak memberikan atribusi langsung kepada Menteri Kelautan dan Perikanan untuk membentuk Peraturan Menteri sebagai tindak lanjut UU Perikanan guna menjamin pengelolaan perikanan berkelanjutan.

Berdasarkan kondisi tersebut, perlu dipikirkan gagasan lain selain penerapan pidana sebagai primum remedium atas korporasi yang dapat menimbulkan efek jera. Apabila menggunakan pendekatan mekanisme perizinan, maka hal tersebut termasuk tindakan pemerintah yang berada dalam bidang hukum administrasi. Penggunaan bidang hukum administrasi, salah satunya dengan memperkuat ancaman sanksi administrasi, yakni dengan mengembalikan fungsi sanksi administrasi yang bersifat primum remedium, dan mengembalikan sanksi pidana dengan sifatnya yang ultimum remedium dalam pelaksanaan UU Perikanan. Hal ini perlu dilakukan dengan mengutamakan asas manfaat selain asas keadilan dan kepastian hukum.

Berdasarkan uraian di atas, maka untuk fokus pada artikel ini untuk menjawab permasalahan sebagai berikut:

1. Bagaimana sanksi administrasi dapat bersifat primum remedium sehingga diharapkan menimbulkan efek jera bagi korporasi?

2. Bagaimana sebaiknya reformulasi sanksi administrasi dalam UU Perikanan?

Lihat Pasal 33 ayat (3) UUD NRI Tahun 1945.

Lihat Konsideran huruf a UU Perikanan.

Lihat Pasal UU Perikanan 
Literatur terkait dengan substansi dalam artikel ini tidak memiliki permasalahan sejenis, sehingga patut disimpulkan bahwa artikel semacam ini belum pernah dibuat sebelumnya. Namun, terdapat beberapa artikel yang dapat mengantarkan pada pemahaman tentang sanksi administrasi bersifat sebagai efek jera. Pertama, Jurnal Upaya Penerapan Sanksi Administratif dan Perizinan Sebagai Pembatasan terhadap Kebebasan Bertindak. ${ }^{4}$ Jurnal ini membahas tema sentral berupa wewenang pemberian sanksi administrasi sebagai konsep hukum publik; dan pemberian izin dan penerapan sanksi sebagai pembatasan kebebasan bertindak. Substansi yang diuraikan seputar sanksi administrasi, komponen wewenang penerapan sanksi administrasi, serta mengaitkannya dengan materi muatan urusan pemerintahan dalam Undang-Undang Nomor 32 Tahun 2004 tentang Pemerintahan Daerah.

Kedua, Jurnal Penegakan Hukum Sanksi Administrasi Terhadap Pelanggaran Perizinan. ${ }^{5}$ Berlatar belakang bahwa sanksi merupakan bagian penutup yang penting di dalam hukum, dimana salah satunya adalah sanksi administrasi, merupakan suatu bentuk pemaksaaan administrasi negara terhadap warganya dalam hal perintah, kewajiban, atau larangan yang diatur dalam peraturan perundang-undangan. Permasalahan yang diuraikan dalam tulisan tersebut yakni bentuk dan jenis sanksi administrasi, serta penerapan sanksi administrasi terhadap pelanggaran perizinan.

Artikel ini memiliki perbedaan dengan ketiga literatur tersebut, dan lebih menitikberatkan pada substansi terkait penempatan sanksi administrasi yang bersifat primum remedium sebagai efek jera bagi korporasi pelanggar ketentuan di bidang perikanan beserta reformulasi sanksi administrasi dalam UU Perikanan.

\section{Metode Penelitian}

Artikel ini dihasilkan dari penelitian yang dilakukan secara yuridis normatif. Menggunakan data sekunder berupa bahan hukum primer, sekunder, dan tersier, serta pendekatan putusan hakim dan perbandingan peraturan perundang-undangan, yang hasilnya disajikan secara analitis preskriptif.

\section{Hasil Dan Pembahasan}

3.1. Sanksi Administrasi dapat Bersifat Primum Remedium sehingga dapat Menimbulkan Efek Jera bagi Korporasi

\subsubsection{Sanksi Administrasi dalam UU Perikanan}

Sebagai negara hukum maka penerapan asas legalitas merupakan hal mutlak, termasuk di bidang hukum administrasi negara. Hal ini penting untuk memberikan kepastian hukum kepada masyarakat sekaligus memberikan kewenangan kepada pejabat tata usaha negara. Asas legalitas berupa wetmatigheid van bestuur atau rechtmatigheid van bestuur merupakan dasar dapat bertindaknya pejabat tata usaha

\footnotetext{
4 Nasution, B.J. (2014). Upaya Penerapan Sanksi Administratif dan Perizinan Sebagai Pembatasan Terhadap Kebebasan Bertindak. Asy-Syir'ah, 48 (1).

5 Raharja, I.V. (2014). Penegakan Hukum Sanksi Administrasi Terhadap Pelanggaran Perizinan. Inovatif, VII (I).
} 
negara berdasarkan hukum dan sesuai dengan kewenangan yang diberikan dari peraturan perundang-undangan. ${ }^{6}$

Penerapan sanksi administrasi dilakukan untuk memperbaiki adanya penyimpangan atas kewajiban dan larangan dalam hubungan hukum administrasi negara, sehingga tujuannya untuk memberikan dampak langsung dan eksekusi langsung kepada pihak yang melanggar, atau dikenal dengan parate executie. ${ }^{7}$ Sanksi dalam peraturan perundang-undangan itu sendiri merupakan bentuk paksaan atas kepatuhan masyarakat manakala terdapat kewajiban dan larangan. Oleh karena itu, penjatuhan sanksi administrasi juga dapat dikatakan sebagai upaya administrasi yang memiliki ciri sebagai berikut:

a. instansi yang mengeluarkan keputusan tata usaha negara atau instansi lain, atau instansi yang lebih tinggi, adalah yang memutuskan sanksi;

b. segi rechtmatigheid dan doelmatigheid;

c. dapat mengganti, mengubah, dan membatalkan keputusan tata usaha negara;

d. dapat memperhatikan perubahan fakta/keadaan saat pemeriksaan (ex-nunc). 8

Norma yang secara langsung mengancam dengan sanksi administrasi dalam UU Perikanan terdapat dalam Pasal 35A ayat (3) dan Pasal 41 ayat (4), sebagai berikut:

Pasal 35A ayat (3):

(1) $\quad \ldots$

(2) Kapal perikanan berbendera asing yang melakukan penangkapan ikan di ZEEI wajib menggunakan anak buah kapal berkewarganegaraan Indonesia paling sedikit $70 \%$ (tujuh puluh persen) dari jumlah anak buah kapal.

(3) Pelanggaran terhadap ketentuan penggunaan anak buah kapal sebagaimana dimaksud pada ayat (2) dikenakan sanksi administratif berupa peringatan, pembekuan izin, atau pencabutan izin.

(4) Ketentuan lebih lanjut mengenai pengenaan sanksi administratif sebagaimana dimaksud pada ayat (3) diatur dalam Peraturan Menteri.

Pasal 41 ayat (4):

(1) $\quad \ldots$

(2) $\quad \ldots$

(3) Setiap kapal penangkap ikan dan kapal pengangkut ikan harus mendaratkan ikan tangkapan di pelabuhan perikanan yang ditetapkan atau pelabuhan lainnya yang ditunjuk.

(4) Setiap orang yang memiliki dan/atau mengoperasikan kapal penangkap ikan dan/atau kapal pengangkut ikan yang tidak melakukan bongkar muat ikan tangkapan di pelabuhan perikanan yang ditetapkan atau pelabuhan lainnya yang ditunjuk sebagaimana dimaksud pada ayat (3) dikenai sanksi administratif berupa peringatan, pembekuan izin, atau pencabutan izin.

6 Ilmar, A. (2014). Hukum Tata Pemerintahan. Jakarta: Kencana, p. 29. Lihat juga Ridwan H.R., op.cit., p. 91, dan Marbun, S.F. (2017). Bahan Kuliah Hukum Administrasi Negara dan PTUN. Program Pascasarjana Ilmu Hukum, Fakultas Hukum Universitas Islam Indonesia.

7 Simatupang, D.P.N. (2016). Penentuan Sanksi Administrasi dalam Undang-Undang. Seminar Kaidah Perumusan Sanksi Administratif dan Sanksi Pidana dalam Undang-Undang. Jakarta: Pusat Perancangan Undang-Undang, Badan Keahlian DPR RI.

${ }^{8}$ Marbun, S.F., loc.cit. 
(5) Ketentuan lebih lanjut mengenai pengenaan sanksi administratif sebagaimana dimaksud pada ayat (4) diatur dalam Peraturan Menteri.

Kedua pasal tersebut merupakan pengaturan terbatas terkait pemberian kewenangan bagi pemberi izin usaha perikanan untuk dapat menegur, membekukan, bahkan menarik kembali atau mencabut izin yang telah diberikan. Paksaan untuk memperbaiki penyimpangan ini dengan kata lain telah memenuhi aspek aturan hukum yang mengatur hubungan hukum. Hanya saja, kedua pasal tersebut tidak dilanjutkan dengan aturan hukum yang mengatur cara bagaimana alat kelengkapan negara dalam hal ini pemberi izin melakukan tugasnya tersebut, karena memberikan atribusi pengaturan lebih lanjut ke dalam peraturan menteri.

Penjatuhan sanksi administrasi sebagai bentuk penegakan hukum administrasi dapat diterapkan terhadap kegiatan yang menyangkut persyaratan perizinan dan peraturan perundang-undangan, dengan tujuan:

a. mencegah terjadinya pelanggaran;

b. upaya memaksa bagi pelaku untuk perbaikan sebagai akibat dari perbuatannya;

c. memberi efek jera bagi pelaku pelanggaran;

d. agar menimbulkan beban ekonomi bagi pelaku untuk membayar sejumlah uang bagi biaya pemulihan dan ganti rugi;

e. agar menimbulkan efek takut bagi pihak lain untuk melakukan pelanggaran hukum;

f. melindungi hak-hak masyarakat dan sekaligus mendorong peningkatan ketaatan hukum masyarakat;

g. meminimalisasi kerugian dan korban; dan

h. mengamankan dan menegakan kebijakan, rencana, dan program pemerintah. ${ }^{9}$

Tujuan tersebut dapat dicapai apabila ketentuan sanksi administrasi dalam UU Perikanan mengatur dengan jelas mekanisme penjatuhan kepada pelanggar, termasuk pemilahan pelanggaran yang sesungguhnya dapat diancamkan dengan sanksi administrasi lebih dahulu, ketimbang sanksi pidana. Materi muatan Pasal 35A ayat (3) dan Pasal 41 yat (4) UU Perikanan sebagaimana telah diuraikan sebelumnya, menunjukkan kelemahan tersebut. Ditambah lagi modus dari pelaku pelanggar ketentuan di bidang perikanan yang diantaranya berupa penggunaan anak buah kapal asing yang tidak dilaporkan, pemalsuan log book, pendaratan ikan hanya untuk memenuhi kewajiban karena sebagian besar ikan hasil tangkapan telah dialihkan muatannya ke kapal lain terlebih dahulu di laut untuk langsung di bawa ke luar negeri (transshipment). ${ }^{10}$

Oleh karena itu, apabila diatur secara jelas peranan sanksi administrasi dapat diterapkan terlebih dahulu menjadikan sehingga sanksi administrasi dapat bersifat Primum Remedium, sekaligus sebagai strategi dengan pendekatan ketaatan (compliance) jenis threat based. ${ }^{11}$

Apabila membandingkan dengan peraturan perundang-undangan lain yang semangatnya menjadikan sanksi administrasi bersifat primum remedium dan

9 Yusuf, A.W. (2016). Sanksi Administrasi dalam Hukum Administrasi Negara. Seminar Kaidah Perumusan Sanksi Administratif dan Sanksi Pidana dalam Undang-Undang. Jakarta: Pusat Perancangan Undang-Undang, Badan Keahlian DPR RI, p. 8.

10 Santosa, M.A.S.A. (2017). Kebijakan Pemberantasan Illegal, Unreported, and Unregulated Fishing. Kuliah Umum dan Orientasi Ke-UGM-an. Yogyakarta: FH UGM.

11 ibid. 
mengembalikan sifat sanksi pidana menjadi ultimum remedium, setidaknya terdapat dua undang-undang yang dapat dijadikan rujukan, yaitu Undang-Undang Nomor 6 Tahun 1983 tentang Ketentuan Umum dan Tata Cara Perpajakan, sebagaimana telah beberapa kali diubah, terakhir dengan Undang-Undang Nomor 16 Tahun 2009 (UU KUP), dan Undang-Undang Nomor 32 Tahun 2009 tentang Perlindungan dan Pengelolaan Lingkungan Hidup (UU PPLH).

Penjelasan Pasal 13A UU KUP dan Penjelasan Umum angka 6 UU PPLH sebagai contohnya, yang berbunyi sebagai berikut:

\begin{abstract}
Penjelasan Pasal 13A UU KUP:
Pengenaan sanksi pidana merupakan upaya terakhir (kursif oleh penulis) untuk meningkatkan kepatuhan Wajib Pajak. Namun, bagi Wajib Pajak yang melanggar pertama kali ketentuan sebagaimana dimaksud dalam Pasal 38 tidak dikenai sanksi pidana, tetapi dikenai sanksi administrasi. Oleh karena itu, Wajib Pajak yang karena kealpaannya tidak menyampaikan Surat Pemberitahuan atau menyampaikan Surat Pemberitahuan, tetapi isinya tidak benar atau tidak lengkap, atau melampirkan keterangan yang isinya tidak benar sehingga dapat menimbulkan kerugian pada pendapatan Negara tidak dikenai sanksi pidana apabila kealpaan tersebut pertama kali dilakukan Wajib Pajak. Dalam hal ini, Wajib Pajak tersebut wajib melunasi kekurangan pembayaran jumlah pajak yang terutang beserta sanksi administrasi berupa kenaikan sebesar 200\% (dua ratus persen) dari jumlah pajak yang kurang dibayar.
\end{abstract}

Penjelasan Umum angka 6 UU PPLH:

Penegakan hukum pidana dalam Undang-Undang ini memperkenalkan ancaman hukuman minimum di samping maksimum, perluasan alat bukti, pemidanaan bagi pelanggaran baku mutu, keterpaduan penegakan hukum pidana, dan pengaturan tindak pidana korporasi. Penegakan hukum pidana lingkungan tetap memperhatikan asas ultimum remedium (kursif dari penulis) yang mewajibkan penerapan penegakan hukum pidana sebagai upaya terakhir setelah penerapan penegakan hukum administrasi dianggap tidak berhasil. Penerapan asas ultimum remedium ini hanya berlaku bagi tindak pidana formil tertentu, yaitu pemidanaan terhadap pelanggaran baku mutu air limbah, emisi, dan gangguan.

Berdasarkan hal tersebut, pengenaan ancaman sanksi pidana dalam UU Perikanan memang tetap diperlukan, hanya saja pengenaan sanksi administratif semestinya lebih diutamakan. Hal ini sejalan dengan pendapat W.F. Prins, sebagaimana dikutip oleh Philipus M. Hadjon dkk., yang menyatakan bahwa hampir setiap peraturan berdasarkan hukum administrasi diakhiri in cauda venenum (ada racun di ekor) dengan sejumlah ketentuan pidana. ${ }^{12}$ Termasuk pendapat Sudarto yang menyatakan bahwa hukum pidana harus dianggap sebagai ultimum remedium, yakni

12 Hadjon, P.M., dkk. (2015). Pengantar Hukum Administrasi Indonesia. Yogyakarta: Gadjah Mada University Press, p. 45-46. 
"obat terakhir" apabila sanksi atau upaya-upaya pada cabang hukum lainnya tidak mempan atau dianggap tidak mempan. ${ }^{13}$

Perumusan sanksi administrasi harus jelas hukuman apa dikenakan terhadap perbuatan apa, karena dalam bidang perundang-undangan terdapat beberapa implikasi yang dimiliki pemerintah berdasarkan freies ermessen. Pertama, kewenangan atas inisiatif sendiri, dalam hal ini kewenangan Presiden membentuk Peraturan Pengganti Undang-Undang. Kedua, kewenangan karena delegasi perundang-undangan dari konstitusi, dalam hal ini Presiden dapat membentuk peraturan pemerintah dan peraturan presiden, atau menteri dapat membentuk peraturan menteri. Selain itu pemerintah juga memiliki droit function, yaitu kekuasaan untuk menafsirkan ketentuan yang bersifat enunsiatif. ${ }^{14}$ Meskipun demikian, pemerintah dilarang melakukan tindakan yang bersifat detournement de pouvoir (melakukan sesuatu di luar tujuan kewenangan yang diberikan) atau onrechtmatige overheidsdaad (perbuatan melawan hukum oleh penguasa), ${ }^{15}$ termasuk juga tidak dapat melakukan perbuatan sewenang-wenang (willekeur). ${ }^{16}$

\subsubsection{Penggunaan Sanksi Administrasi Sebagai Efek Jera bagi Korporasi}

Kaidah peraturan perundang-undangan di bidang hukum administrasi sering tidak hanya memuat satu ancaman sanksi tetapi terdapat beberapa macam sanksi yang diberlakukan secara kumulasi. Ketidakjelasan dan tidak dapat dilaksanakannya rumusan sanksi yang diancamkan kepada korporasi dalam UU Perikanan sebagaimana telah diuraikan sebelumnya, menyebabkan pengenaan sanksi administrasi yang diberikan oleh Kementerian Kelautan dan Perikanan pada tahun 2015 dilakukan dengan menggunakan diskresi.

Penggunan diskresi ini dilakukan melalui penerbitan keputusan menteri yang memberikan sanksi administrasi berupa pembekuan dan pencabutan izin terhadap korporasi yang dianggap melakukan pelanggaran di bidang perikanan tangkap setelah dilakukan analisa dan evaluasi oleh tim yang dibentuk Menteri Kelautan dan Perikanan, yakni dengan memberikan sanksi pencabutan izin usaha perikanan (SIUP) dari 8 Perusahaan, dan mencabut izin penangkapan ikan (SIPI) serta izin kapal pengangkutan ikan (SIKPI) dari 12 perusahaan. Pencabutan SIUP ini membuat korporasi tidak dapat lagi melakukan kegiatan usaha perikanan, dan bagi perusahaan yang terkena pencabutan SIPI dan SIKPI harus melakukan perbaikan kegiatan usaha sebagai syarat mengajukan perizinan baru agar dapat melakukan kegiatan penangkapan dan pengangkutan ikan lagi. ${ }^{17}$

Meskipun kemudian terdapat 3 perusahaan yang mengajukan perlawanan hukum melalui gugatan tata usaha negara, karena keberatan atas pencabutan izin yang mereka miliki, tetapi putusan majelis hakim pada Pengadilan Tata Usaha Negara Jakarta tidak mengabulkan permohonan tersebut dan menguatkan keputusan yang mencabut perizinan masing-masing perusahaan. ${ }^{18}$ Dari peristiwa ini, terlihat bahwa

13 Sudarto. (1990). Hukum Pidana I, cetakan ke II. Semarang: Yayasan Sudarto, p. 13.

14 Utrecht, E. (1960). Pengantar Hukum Administrasi Negara Indonesia, Fakultas Hukum Universitas Padjadjaran, Bandung, sebagaimana dikutip dalam Marbun, S.F. dan Moh. Mahfud M.D., op.cit., p. 46-47.

15 ibid, p. 47.

16 Ilmar, A. (2014). Hukum Tata Pemerintahan. Jakarta: Kencana, op.cit., p. 19.

17 Santosa, M.A.S.A., loc.cit.

18 Biro Hukum dan Organisasi. (2016). "Data Penanganan Kasus Hukum 2016", Sekretariat Jenderal Kementerian Kelautan dan Perikanan. 
dijatuhkannya sanksi administrasi membuat perusahaan atau korporasi lebih jera, karena harus melakukan perbaikan apabila ingin melakukan kegiatan usaha perikanan.

Secara teori hukum administrasi, menteri sebagai pejabat tata usaha negara, dapat menempuh langkah kebijaksanaan tersebut karena penggunaan freies ermessen, yang membolehkan seorang pejabat tata usaha negara merumuskan kebijaksanaannya dalam bentuk juridische regels, seperti peraturan, pedoman, pengumuman, surat edaran, dan mengumumkan kebijaksanaan itu. Pada hakikatnya, suatu peraturan kebijaksanaan itu merupakan produk dari perbuatan tata usaha negara yang bertujuan naar buiten gebracht schriftelijk beleid (menampakan keluar suatu kebijakan tertulis). Hal tersebut harus dikaitkan dengan kewenangan pemerintahan atas dasar penggunaan discretionaire karena jika tidak demikian, tidak ada tempat bagi peraturan kebijaksanaan. ${ }^{19}$

Hal ini yang turut menjadi salah satu pertimbangan majelis hakim dalam memberikan putusan. Secara umum, dalam ke-empat perkara tersebut majelis hakim menganggap pengambilan diskresi telah dilakukan secara hati-hati terutama dengan pembentukan tim analisa dan evaluasi terlebih dahulu untuk mengetahui tingkat kesalahan dari suatu korporasi sebelum dilakukan pengambilan keputusan, termasuk menolak permohonan untuk menunda pelaksanaan keputusan tersebut, karena pada dasarnya gugatan tidak menunda pelaksanaan keputusan tata usaha negara. ${ }^{20}$

Pentingnya penggunaan diskresi dalam penegakan hukum, sebagai langkah memberikan efek jera kepada korporasi pelanggar ketentuan di bidang perikanan, dikarenakan:

a. Tidak ada perundang-undangan yang sedemikian lengkapnya, sehingga dapat mengatur semua perilaku manusia;

b. Adanya kelambatan-kelambatan untuk menyesuaikan perundang-undangan dengan perkembangan-perkembangan di dalam masyarakat, sehingga menimbulkan ketidakpastian;

c. Kurangnya biaya untuk menerapkan perundang-undangan sebagaimana dikehendaki oleh pembentuk undang-undang;

d. Adanya kasus-kasus individual yang memerlukan penanganan secara khusus. ${ }^{21}$

Diskresi dibutuhkan sebagai pelengkap daripada asas legalitas, yaitu asas hukum yang menyatakan bahwa setiap tindak atau perbuatan administrasi negara harus berdasarkan ketentuan undang-undang. Pada diskresi bebas, undang-undang hanya menetapkan batas-batas, dan administrasi negara bebas mengambil keputusan apa saja asalkan tidak melampaui/melanggar batas-batas tersebut. Pada diskresi terikat, undang-undang menerapkan beberapa alternatif dan administrasi negara bebas memilih salah satu alternatif. ${ }^{22}$

19 Hadjon, P.M., dkk. Op.cit., p. 147-148.

20 Lihat Putusan Pengadilan Tata Usaha Negara Jakarta Nomor 203/G/2015/PTUN-JKT, Nomor 204/G/2015/PTUN-JKT, dan Nomor 205/G/2015/PTUN-JKT yang diucapkan pada sidang terbuka tanggal 23 Juni 2016, serta Nomor 211/G/2015/PTUN-JKT yang diucapkan pada sidang terbuka tanggal 20 April 2016.

21 LaFave, W.R. (1964). The Decision to take a Suspect Into Custody, Brown and Company, Boston, sebagaimana dikutip dalam Soekanto, S. (2016), Faktor-faktor yang Mempengaruhi Penegakan Hukum, op.cit, p. 21-22.

22 Atmosudirdjo, P. (1983). Hukum Administrasi Negara, Ghalia Indonesia, Jakarta, sebagaimana dikutip dalam Soekanto, S. (2016). Faktor-faktor yang Mempengaruhi Penegakan Hukum. Jakarta: RajaGrafindo, p. 22. 
Untuk menentukan pengenaan sanksi administrasi secara bertahap, bebas, atau kumulatif, pejabat yang berwenang mengenakan sanksi mendasarkan pada pertimbangan:

a. berat-ringannya jenis pelanggaran;

b. tingkat penataan terhadap pemenuhan perintah atau kewajiban yang ditentukan dalam sanksi administratif;

c. rekam jejak ketaatan penanggung jawab usaha dan/atau kegiatan; dan/atau

d. tingkat pengaruh atau implikasi pada masyarakat dan/atau lingkungan hidup. ${ }^{23}$

Hanya saja, pejabat tata usaha negara dalam hal melakukan pencabutan izin sebagai upaya penjeraan kepada korporasi, perlu memperhatikan dua syarat, yakni:

a. Pemilik izin tidak mematuhi pembatasan-pembatasan, syarat-syarat atau ketentuan peraturan perundang-undangan;

b. Pemegang izin pada waktu mengajukan permohonan untuk mendapatkan izin, subsidi, atau pembayaran telah memberikan data sedemikian tidak benar atau tidak lengkap, hingga apabila data itu diberikan secara benar atau lengkap maka keputusan akan berlainan. ${ }^{24}$

\subsection{Reformulasi Sanksi Administrasi dalam Undang-Undang Perikanan}

3.2.1 Pemilahan Sanksi Administrasi

Hukum administrasi, dikatakan oleh Harlow dan Rawlings, adalah the law relating to public administration, yaitu hukum yang berhubungan dengan administrasi publik. Berhubungan dengan cara atau upaya dengan mana pemerintahan menjalankan tugas yang diberikan kepadanya, termasuk mengenai hakikat kekuasaan itu dan tugas serta cara bagaimana kekuasaan itu dikendalikan. ${ }^{25}$

Perumusan sanksi administrasi dalam undang-undang seharusnya jelas pada penyimpangan apa saja, sehingga rumusan norma sanksi administrasi dan sanksi pidana tidak dapat ditafsirkan berlainan. Untuk itu, perlu ditentukan dalam tindakan hukum administrasi mana yang jika disimpangi akan dikenakan sanksi administrasi dan bukan sanksi lainnya ${ }^{26}$. Pembentukan norma hukum yang bersifat umum dan abstrak (general and abstract legal norms) berupa peraturan yang bersifat tertulis (statutory form), pada umumnya didasarkan atas beberapa hal, yaitu:

a. Pembentukannya diperintahkan oleh UUD NRI 1945; dan

b. Pembentukannya dianggap perlu karena kebutuhan hukum. ${ }^{27}$

Selain itu, dalam perumusan suatu undang-undang harus dipahami terlebih dahulu legal concept yang akan diatur sebagai penyempurnaan, dalam hal ini UU Perikanan. ${ }^{28}$ Sebagai perbandingan, dalam Undang-Undang Nomor 32 Tahun 2009 tentang Perlindungan dan Pengelolaan Lingkungan Hidup, terdapat pengaturan restorative justice berupa penyelesaian sengketa lingkungan hidup di luar pengadilan

23 Yusuf, A.W. op.cit., p. 19.

24 Hadjon, P.M. dkk, op.cit., p. 250.

25 Harlow, C. dan R. Rawlings. (1997). Law and Administration, Butterworths, London, p. 1-2, sebagaimana dikutip dalam Asshiddiqie, J. (2013). Pengantar Ilmu Hukum Tata Negara, PT RajaGrafindo, Jakarta, p. 67.

26 Simatupang, D.P.N., loc.cit.

27 Asshiddiqie, J. (2014). Perihal Undang-Undang. Jakarta: PT RajaGrafindo, p. 179.

28 Haggard, T.R. dan David W. Robinson Chair. (1996). Legal Drafting in a Nutshell, West Publishing, Minnesota, p. 83. 
melalui tindakan pemulihan akibat pencemaran dan/atau perusakan, sehingga secara ekonomi ada timbal balik bagi negara ${ }^{29}$.

Artinya, pemilahan sanksi administrasi semestinya mendapatkan porsi yang cukup dan mekanisme yang jelas, untuk menghindari kelemahan yang diciptakan dari ancaman sanksi pidana. Selain itu, pengaturan sanksi administrasi ditujukan untuk melakukan pencegahan terjadinya pelanggaran yang lebih meluas atau lebih merugikan dan pengenaannya lebih kepada perbaikan kondisi semula.

\subsubsection{Reformulasi Norma UU Perikanan}

Formulasi norma dalam suatu bentuk peraturan perundang-undangan di Indonesia tidak dapat terlepas dari konstitusi yakni UUD NRI Tahun 1945 dan sumber segala sumber hukum yakni Pancasila. Perkembangan pemikiran ekonomi yang kini lebih berorientasi pasar dengan mengikuti kenyataan yang berkembang dalam masyarakat yang makin terbuka, berhadapan dengan konstitusi sebagai hukum tertinggi sebagai acuan yang utama. Dalam hubungan tersebut, maka UUD NRI Tahun 1945 dapat dipahami sebagai konstitusi politik, sekaligus konstitusi ekonomi dan sosial. Konstitusi Politik mengatur dinamika dalam kehidupan bernegara (state), Konstitusi Sosial mengatur kehidupan bermasyarakat (civil society), dan konstitusi ekonomi mengatur dinamika yang terjadi di dunia usaha dan pasar (market) ${ }^{30}$

Menurut Jimly Asshiddiqie, dalam perspektif konstitusi ekonomi tidak perlu terjebak dalam diskusi mengenai ideologi ekonomi. Untuk itu, masih menurut Jimly, yang terpenting adalah merumuskan rambu-rambu pokok mengenai dasar kebijakan ekonomi dalam konstitusi sebagai dokumen hukum, dokumen politik, dan dokumen ekonomi tertinggi, karena konstitusi merupakan kontrak sosial yang dapat saja berubah atau diubah setiap saat diperlukan. Namun demikian, selama konstitusi itu berlaku maka kesepakatan tertinggi itulah yang harus dijadikan referensi tertinggi dalam mengembangkan kebijakan ekonomi, ${ }^{31}$ termasuk di dalamnya pengelolaan perikanan.

Melalui pendekatan ekonomi pula, pengaturan sanksi administrasi agar ada efek jera bagi korporasi, perlu menggunakan analisis ke-ekonomian tentang hukum (economic analysis of law) yang memiliki konsep dasar sebagai berikut:

a. konsep pilihan rasional (rational choice), menitikberatkan pada pertimbangan untung-rugi, kelebihan-kekurangan, kemampuan-keterbatasan;

b. konsep nilai (value), menitikberatkan pada pengharapan keuntungan-kerugian, baik nilai materi maupun non-materi, dan ditujukan pada relevansi peningkatan kemakmuran;

c. konsep efisiensi (efficiency), menitikberatkan pada penghematan, keberhasilan maksimum dalam suatu tindakan, tepat sasaran, termasuk mencapai kepuasan; dan

d. konsep utilitas (utility), menitikberatkan pada manfaat, melihat ketidakpastian keuntungan dan kerugian yang mengarah pada konsep risiko. ${ }^{32}$

29 Lihat Pasal 85 ayat (1) UU No. 32 Tahun 2009.

30 Asshiddiqie, J. (2016). Konstitusi Ekonomi, PT Kompas Media Nusantara, Jakarta, p. 70 .

31 ibid., p. 71-72.

32 Sugianto, F. (2013). Economic Analysis of Law, Seri I. Jakarta: Kencana, p. 33-39. 
Analisis ke-ekonomian tersebut diperlukan karena pada prinsipnya, pengelolaan perikanan merupakan bentuk pelaksanaan atas penguasaan negara terhadap sumber daya alam karena sebagai tindak lanjut amanat Pasal 33 ayat (3) UUD NRI Tahun 1945, yang dapat dinyatakan sebagai salah satu substansi konstitusi ekonomi karena memuat kebijakan ekonomi khususnya atas sumber daya alam. Kebijakan inilah yang memberi payung dan arahan bagi perkembangan kegiatan ekonomi Indonesia melalui pengelolaan perikanan. ${ }^{33}$

Berdasarkan hal tersebut, perumusan norma dalam UU Perikanan harus didasarkan atas norma hukum konstitusional tersebut yang bersifat mutlak tidak boleh dilanggar oleh penentu kebijakan ekonomi yang bersifat operasional. ${ }^{34}$ Namun, pengertian "dikuasai oleh negara" harus dipahami tidak identik dengan "dimiliki oleh negara". negara cukup berperan sebagai regulator, bukan pelaku langsung. ${ }^{35}$ Apabila dibandingkan dengan rumusan yang mirip dalam konstitusi negara lain, ketentuan "dikuasai oleh negara" ada yang menggunakan istilah owned by, belong to, atau ada yang tegas menyebutnya sebagai state's property. ${ }^{36}$

Dari uraian tersebut dapat disarikan bahwa reformulasi UU Perikanan harus mengacu dan berdasarkan konstitusi karena supremasi konstitusi merupakan salah satu pokok sistem pemerintahan Indonesia (the supreme of constitution), selain Indonesia merupakan negara berdasar atas hukum (rechtsstaat), sehingga peraturan perundang-undangan memegang salah satu peranan penting dalam penyelenggaraan negara.

Menurut Philipus M. Hadjon, ide rechtsstaat cenderung ke arah positivisme hukum yang membawa konsekuensi bahwa hukum harus dibentuk secara sadar oleh badan pembentuk undang-undang, ${ }^{37}$ dan lembaga yang berwenang membentuk peraturan perundang-undangan di bawah undang-undang.

\subsubsection{Ruang Lingkup Materi Muatan Formulasi Sanksi Administrasi}

Dari ulasan dan pencermatan materi muatan baik dalam UU Perikanan maupun tindak lanjutnya dalam peraturan menteri yang telah diuraikan sebelumnya, terdapat beberapa pelanggaran yang sebaiknya dikenakan sanksi administrasi terlebih dahulu, atau dengan kata lain menempatkan sanksi administrasi sebagai primum remedium, meskipun sanksi administrasi tidak dapat menghapuskan kesalahan yang harus ditindak dengan sanksi pidana sebagai ultimum remedium.

Untuk mempermudah reformulasi sanksi administrasi, maka pemilahan ruang lingkup materi muatan dilakukan dengan cara sebagai berikut:

a. menganalisa beberapa ketentuan berupa tindak pidana pelanggaran, apabila secara perbuatan lebih menitikberatkan pada proses administrasi, maka sebaiknya dirumuskan dengan pemberian ancaman sanksi administratif terlebih dahulu;

b. ketentuan yang mengatur ancaman sanksi administratif yang belum jelas pengaturannya, agar diperjelas mekanismenya;

33 Asshiddiqie, J. Konstitusi Ekonomi, op.cit., p. 68.

34 ibid., p. 69.

35 ibid., p. 246.

36 ibid., p. 274.

37 Hadjon, P.M. "Ide Negara Hukum dalam Sistem Ketatanegaraan Republik Indonesia", disampaikan pada Simposium Politik, Hak Asasi Manusia, dan Pembangunan, dalam rangka Dies Natalis Universitas Airlangga, Surabaya, 3 November 1994, sebagaimana dikutip dalam Ridwan H.R., op.cit., p. 21. 
c. menganalisa perbuatan yang lebih bersifat administratif, agar dilakukan dekriminalisasi, dengan cukup diselesaikan melalui sanksi administratif;

d. perbuatan yang memang memiliki risiko tinggi atas kerusakan sumber daya alam, perbuatan yang mengancam keamanan nasional, dan perbuatan yang menyangkut kedaulatan negara, agar tetap dirumuskan dengan mengutamakan sanksi pidana.

Dari penggunaan cara tersebut, didapati ruang lingkup perbuatan yang sebaiknya masuk dalam klasifikasi ancaman sanksi administrasi untuk dimuat dalam UU Perikanan yang akan datang atau ius constituendum, meliputi pengelolaan perikanan, operasional perikanan tangkap, perikanan budidaya, serta konservasi.

Reformulasi sanksi administrasi dalam UU Perikanan, meskipun menjadikan sanksi administrasi menjadi primum remedium, pada prinsipnya tetap memegang asas bahwa penjatuhan sanksi administrasi tidak menghapus kesalahan untuk dapat dituntut pertanggungjawaban pidananya. Oleh karena itu pemilihan ruang lingkup perbuatan yang sebaiknya masuk dalam klasifikasi ancaman sanksi administrasi tersebut, lebih menekankan pada upaya memperbaiki adanya penyimpangan atas kewajiban dan larangan dalam hubungan hukum administrasi. 
Adapun saran formulasi sanksi administrasi untuk dimuat dalam UU Perikanan yang akan datang atau ius constituendum, sebagai berikut:

Tabel Reformulasi Sanksi Administrasi UU Perikanan.

\begin{tabular}{|c|c|c|c|c|}
\hline No & Substansi & Ancaman & Reformulasi & Sifat Pidana \\
\hline \multirow[t]{10}{*}{1} & $\begin{array}{l}\text { Pasal } 7 \text { ayat (2), kewajiban } \\
\text { mematuhi ketentuan mengenai: }\end{array}$ & \multirow{10}{*}{$\begin{array}{l}\text { a. Pasal 100, diancam pidana } \\
\text { denda paling banyak } \\
\text { 250.000.000; } \\
\text { b. Pasal 100C untuk nelayan } \\
\text { kecil dan/atau } \\
\text { pembudidaya-ikan kecil } \\
\text { diancam pidana denda } \\
\text { paling banyak } \\
\text { 100.000.000,- }\end{array}$} & \multirow{10}{*}{$\begin{array}{l}\text { (1) Pelanggaran terhadap ketentuan } \\
\text { sebagaimana dimaksud dalam Pasal } 7 \\
\text { ayat (2) huruf a sampai dengan huruf } \\
\text { k, dikenakan sanksi administratif } \\
\text { berupa: } \\
\text { a. teguran; } \\
\text { b. pembekuan izin; atau } \\
\text { c. pencabutan izin. } \\
\text { (2) Sanksi administratif sebagaimana } \\
\text { dimaksud pada ayat (1) dapat } \\
\text { dikenakan secara langsung tanpa } \\
\text { bertahap. pelanggaran dilakukan } \\
\text { (3) Dalam hal pecil dan/atau } \\
\text { oleh nelayan kilakukan } \\
\text { pembudidaya-ikan kecil, dilaking } \\
\text { pembinaan oleh Pemerintah Pusat } \\
\text { dan pemerintah daerah. } \\
\text { (4) Dalam hal pelanggaran menimbulkan } \\
\text { kerugian negara, dapat dikenakan } \\
\text { sanksi berupa penggantian kerugian. }\end{array}$} & \multirow[t]{10}{*}{$\begin{array}{lr}\text { Ancaman } & \text { pidana } \\
\text { menjadi } & \text { ultimum } \\
\text { remedium } & \end{array}$} \\
\hline & $\begin{array}{l}\text { a. jenis, jumlah, dan ukuran alat } \\
\text { penangkapan ikan; }\end{array}$ & & & \\
\hline & $\begin{array}{l}\text { b. jenis, jumlah, ukuran, dan } \\
\text { penempatan alat bantu } \\
\text { penangkapan ikan; }\end{array}$ & & & \\
\hline & $\begin{array}{l}\text { c. daerah, jalur, dan waktu atau } \\
\text { musim penangkapan ikan; }\end{array}$ & & & \\
\hline & $\begin{array}{l}\text { d. persyaratan atau standar } \\
\text { prosedur operasional } \\
\text { penangkapan ikan; }\end{array}$ & & & \\
\hline & $\begin{array}{l}\text { e. sistem pemantauan kapal } \\
\text { perikanan; }\end{array}$ & & & \\
\hline & $\begin{array}{l}\text { f. jenis ikan baru yang akan } \\
\text { dibudidayakan; }\end{array}$ & & & \\
\hline & $\begin{array}{l}\text { g. jenis ikan dan wilayah } \\
\text { penebaran kembali } \begin{array}{r}\text { serta } \\
\text { penangkapan ikan berbasis } \\
\text { budi daya; }\end{array} \\
\end{array}$ & & & \\
\hline & $\begin{array}{l}\text { h. pembudidayaan ikan dan } \\
\text { perlindungannya; }\end{array}$ & & & \\
\hline & $\begin{array}{l}\text { i. pencegahan pencemaran dan } \\
\text { kerusakan sumber daya ikan } \\
\text { serta lingkungannya; }\end{array}$ & & & \\
\hline
\end{tabular}


JUrnal ESENSI HUKUM,

Vol. 1 No. 1 Bulan Desember Tahun 2019, hlm. 51-69

\begin{tabular}{|c|c|c|c|c|}
\hline No & Substansi & Ancaman & Reformulasi & Sifat Pidana \\
\hline & $\begin{array}{l}\text { j. ukuran atau berat minimum } \\
\text { jenis ikan yang boleh } \\
\text { ditangkap; }\end{array}$ & & & \\
\hline & k. kawasan konservasi perairan; & & & \\
\hline \multirow[t]{3}{*}{2} & $\begin{array}{l}\text { Pasal } 20 \text { (1): } \\
\text { Kewajiban memenuhi } \\
\text { persyaratan } \\
\begin{array}{l}\text { pengolahan ikan, sistem jaminan } \\
\text { mutu, dan keamanan hasil } \\
\text { perikanan. }\end{array}\end{array}$ & - & \multirow{3}{*}{$\begin{array}{l}\text { (1) Pelanggaran terhadap ketentuan } \\
\text { dalam Pasal } 20 \text { ayat (1), ayat (3), ayat } \\
\text { (6), dan ayat (7) dikenakan sanksi } \\
\text { administratif berupa: } \\
\text { a. teguran; } \\
\text { b. pembekuan izin; atau } \\
\text { c. pencabutan izin. } \\
\text { (2) Sanksi administratif sebagaimana } \\
\text { dimaksud pada ayat (1) dapat } \\
\text { dikenakan secara langsung tanpa } \\
\text { bertahap. } \\
\text { (3) Pengenaan sanksi pembekuan izin } \\
\text { dapat disertakan pencabutan sertifikat } \\
\text { di bidang kelayakan pengolahan ikan, } \\
\text { sistem jaminan mutu, dan keamanan } \\
\text { hasil perikanan. }\end{array}$} & - \\
\hline & $\begin{array}{l}\text { Pasal } 20 \text { (3): } \\
\text { Kewajiban memenuhi dan } \\
\text { menerapkan persyaratan } \\
\text { kelayakan pengolahan ikan, } \\
\text { sistem jaminan mutu, dan } \\
\text { keamanan hasil perikanan. }\end{array}$ & $\begin{array}{l}\text { Pasal 89, diancam pidana } \\
\text { penjara paling lama } 1 \text { tahun } \\
\text { dan denda paling banyak } \\
800.000 .000,-\end{array}$ & & Dekriminalisasi \\
\hline & $\begin{array}{l}\text { Pasal } 20 \text { (6) dan ayat (7): } \\
\text { Keharusan memenuhi standar } \\
\text { mutu dan keamanan hasil } \\
\text { perikanan. }\end{array}$ & - & & - \\
\hline 3 & $\begin{array}{l}\text { Pasal } 35 \text { (1): } \\
\text { Kewajiban mendapat persetujuan } \\
\text { Menteri terlebih dahulu untuk } \\
\text { membangun, mengimpor, atau } \\
\text { memodifikasi kapal perikanan. }\end{array}$ & $\begin{array}{l}\text { Pasal 95, diancam pidana } \\
\text { penjara paling lama } 1 \text { tahun } \\
\text { dan denda paling banyak } \\
600.000 .000,-\end{array}$ & $\begin{array}{l}\text { (1) Pelanggaran terhadap ketentuan } \\
\text { dalam Pasal } 35 \text { ayat (1) dikenakan } \\
\text { sanksi administratif berupa paksaan } \\
\text { pemerintah. } \\
\text { (2) Paksaan pemerintah sebagaimana } \\
\text { dimaksud pada ayat (1) berupa: } \\
\text { a. menghentikan pembangunan atau } \\
\text { modifikasi kapal perikanan; } \\
\text { b. perubahan spesifikasi kapal; atau }\end{array}$ & $\begin{array}{l}\text { Sanksi Pidana bersifat } \\
\text { ultimum remedium }\end{array}$ \\
\hline
\end{tabular}




\begin{tabular}{|c|c|c|c|c|}
\hline No & Substansi & Ancaman & Reformulasi & Sifat Pidana \\
\hline & & & $\begin{array}{l}\text { c. mengembalikan spesifikasi kapal } \\
\text { seperti semula. } \\
\text { (3) Pengenaan paksaan pemerintah dapat } \\
\text { dijatuhkan tanpa didahului teguran. }\end{array}$ & \\
\hline \multirow[t]{2}{*}{4} & $\begin{array}{l}\text { Pasal 35A (1): } \\
\text { Kewajiban menggunakan } \\
\text { nakhoda dan anak buah kapal } \\
\text { berkewarganegaraan Indonesia } \\
\text { bagi kapal berbendera Indonesia. }\end{array}$ & - & \multirow[t]{2}{*}{$\begin{array}{l}\text { an } \\
\text { tif } \\
\text { tif }\end{array}$} & - \\
\hline & $\begin{array}{l}\text { Pasal 35A (2): } \\
\text { Penggunaan anak buah kapal } \\
\text { berkewarganegaraan Indonesia } \\
\text { paling sedikit } 70 \% \text { bagi kapal } \\
\text { perikanan berbendera asing yang } \\
\text { melakukan penangkapan di ZEEI. }\end{array}$ & $\begin{array}{l}\text { Sanksi administratif berupa } \\
\text { peringatan, pembekuan izin, } \\
\text { atau pencabutan izin, diatur } \\
\text { lebih lanjut dalam Peraturan } \\
\text { Menteri }\end{array}$ & & - \\
\hline 5 & $\begin{array}{l}\text { Pasal } 38(3) \text { : } \\
\text { Kewajiban menyimpan alat } \\
\text { penangkapan ikan di dalam palka } \\
\text { bagi kapal berbendera asing } \\
\text { selama berada di luar daerah } \\
\text { penangkapan ikan yang } \\
\text { diizinkan. }\end{array}$ & $\begin{array}{l}\text { Pasal 97, diancam pidana } \\
\text { denda paling } \\
500.000 .000,-\end{array}$ & \multirow{2}{*}{$\begin{array}{l}\text { (1) Pelanggaran terhadap ketentuan } \\
\text { dalam Pasal } 38 \text { ayat (3) Pasal } 41 \text { ayat } \\
\text { (3), dan Pasal } 42 \text { ayat (3) dikenakan } \\
\text { sanksi administratif berupa: } \\
\text { a. teguran; } \\
\text { b. pembekuan izin; atau } \\
\text { c. pencabutan izin. } \\
\text { (2) Sanksi administratif sebagaimana } \\
\text { dimaksud pada ayat (1) dapat } \\
\text { dikenakan secara langsung tanpa } \\
\text { bertahap. } \\
\text { (3) Pengenaan sanksi administratif tidak } \\
\text { membebaskan dari ancaman sanksi }\end{array}$} & $\begin{array}{l}\text { Sanksi Pidana bersifat } \\
\text { ultimum remedium }\end{array}$ \\
\hline 6 & $\begin{array}{l}\text { Pasal 41 (3): } \\
\text { Keharusan mendaratkan ikan } \\
\text { tangkapan di pelabuhan } \\
\text { perikanan yang ditetapkan atau } \\
\text { pelabuhan lain yang ditunjuk } \\
\text { bagi kapal penangkap ikan dan }\end{array}$ & $\begin{array}{l}\text { Sanksi administratif berupa } \\
\text { peringatan, pembekuan izin, } \\
\text { atau pencabutan izin, diatur } \\
\text { lebih lanjut dalam Peraturan } \\
\text { Menteri }\end{array}$ & & - \\
\hline
\end{tabular}


Jurnal ESENSI HUKUM,

Vol. 1 No. 1 Bulan Desember Tahun 2019, hlm. 51-69

\begin{tabular}{|c|c|c|c|c|}
\hline No & Substansi & Ancaman & Reformulasi & Sifat Pidana \\
\hline & kapal pengangkut ikan. & & \multirow{2}{*}{ pidana. } & \\
\hline 7 & $\begin{array}{l}\text { Pasal } 42(3) \text { : } \\
\text { Kewajiban memiliki Surat } \\
\text { Persetujuan Berlayar yang } \\
\text { dikeluarkan oleh syahbandar di } \\
\text { pelabuhan perikanan. }\end{array}$ & $\begin{array}{l}\text { Pasal 98, diancam pidana } \\
\text { penjara paling lama } 1 \text { tahun } \\
\text { dan denda paling banyak } \\
200.000 .000,-\end{array}$ & & $\begin{array}{l}\text { Sanksi Pidana bersifat } \\
\text { ultimum remedium }\end{array}$ \\
\hline 8 & $\begin{array}{l}\text { Pasal } 55(3) \text { : } \\
\text { Keharusan menyerahkan hasil } \\
\text { penelitian kepada Pemerintah. }\end{array}$ & - & $\begin{array}{l}\text { (1) Pelanggaran terhadap ketentuan } \\
\text { dalam Pasal } 55 \text { ayat (3) dikenakan } \\
\text { sanksi administratif berupa: } \\
\text { a. paksaan pemerintah; atau } \\
\text { b. denda administratif. } \\
\text { (2) Paksaan pemerintah sebagaimana } \\
\text { dimaksud pada ayat (1) huruf a, } \\
\text { berupa: } \\
\text { a. penyitaan hasil penelitian; } \\
\text { b. perampasan hasil penelitian; } \\
\text { c. pemusnahan hasil penelitian; atau } \\
\text { d. daftar hitam peneliti. } \\
\text { (3) Denda administratif sebagaimana } \\
\text { dimaksud pada ayat (1) huruf b, } \\
\text { ditetapkan oleh Menteri berdasarkan } \\
\text { tingkat kepentingan hasil penelitian. } \\
\text { (4) Pengenaan paksaan pemerintah atau } \\
\text { denda administratif dijatuhkan tanpa } \\
\text { didahului teguran. }\end{array}$ & - \\
\hline
\end{tabular}

Sumber: UU Perikanan, diolah oleh penulis. 
Tindak lanjut atas ancaman sanksi administratif tersebut perlu ditindaklanjuti untuk diatur dalam Peraturan Pemerintah, sebagai pengaturan bagaimana cara pelaksanaan/penjatuhan sanksi administrasi tersebut.

Reformulasi sanksi administrasi UU Perikanan termasuk dalam proses pembentukan peraturan perundang-undangan yang memiliki unsur seni, bahkan oleh L.J. van Apeldoorn dinyatakan sebagai kesenian hukum yang utama. Kesenian tersebut terbagi dalam politik perundang-undangan, dan teknik perundang-undangan. ${ }^{38}$

Oleh karena itu, meskipun menggunakan dasar teknik pembentukan yang sama dapat dimungkinkan adanya perbedaan selera dalam penggunaan diksi dan tata letak dalam perumusan suatu pasal atau ayat. Terutama dalam hal perumusan sanksi administrasi, telah ditentukan dalam ketentuan angka 64 sampai dengan angka 66 Lampiran II Undang-Undang Nomor 12 Tahun 2011 tentang Pembentukan Peraturan Perundang-undangan, bahwa letak sanksi administrasi dirumuskan menjadi satu bagian dengan norma yang memberikan ancaman sanksi tersebut, baik dalam ayat terakhir dalam suatu pasal ataupun menjadi pasal terakhir dalam suatu bab, dan tidak dibuat dalam bab tersendiri. Akibatnya, apabila sanksi administrasi menyebar ke dalam beberapa pasal menjadi seolah terdapat beberapa rumusan ancaman sanksi administrasi yang diulang meskipun atas perbuatan yang berbeda.

\section{Kesimpulan}

Berdasarkan uraian dan pemaparan dalam bab-bab sebelumnya, dapat diambil kesimpulan sebagai berikut:

1. Setiap perumusan ketentuan dalam UU Perikanan, dalam hal akan ada risiko pelanggaran, maka perlu diancamkan dengan sanksi baik administrasi maupun pidana. Keterbatasan mekanisme penjatuhan sanksi pidana bagi korporasi, membuat sanksi administrasi seharusnya lebih diutamakan, sehingga sanksi administrasi dapat bersifat primum remedium dengan mengembalikan sanksi pidana menjadi ultimum remedium. Ancaman sanksi administrasi kepada korporasi berupa pembekuan atau pencabutan izin lebih memberikan efek jera ketimbang sanksi pidana, karena dalam penjatuhan sanksi pidana yang dikenakan adalah pegawai atau pengurus perusahaan saja, sedangkan sanksi administrasi berupa pembekuan atau pencabutan izin membuat perusahaan tidak dapat lagi beroperasi.

2. Rumusan sanksi administrasi dalam ius constitutum UU Perikanan tidak diuraikan dengan jelas sehingga dalam pelaksanaannya dibutuhkan diskresi yang dilakukan oleh menteri. Untuk itu, dalam pembentukan ius constituendum UU Perikanan, harus dilakukan pemilahan pelanggaran yang sebaiknya diancamkan dengan sanksi administrasi terlebih dahulu dengan melihat potensi dampak yang ditimbulkan atas pelanggaran tersebut sekaligus melakukan harmonisasi dengan

38 Apeldoorn, L.J.V. (1982). Pengantar Ilmu Hukum, Pradnya Paramita, Jakarta, p. 390. 
undang-undang terkait. Pemilahan tersebut termasuk mempertimbangkan efek jera bagi korporasi.

\section{Ucapan terima Kasih (Acknowledgments)}

Penulis menyampaikan terima kasih kepada para pihak yang telah banyak membantu penelitian dan penulisan artikel ini, Aminoto, S.H., M.Si (Almarhum) yang telah banyak membimbing dalam penelitian dan penulisan artikel ini, Dr. Tini Martini, S.H., M.Soc.Sci, selaku Kepala Biro Hukum dan Organisasi, Kementerian Kelautan dan Perikanan, yang memberikan kesempatan penulis untuk meraih pendidikan yang lebih tinggi, serta kepada Unit Riset dan Publikasi FH UGM yang telah memberikan kesempatan penulis melakukan penelitian. Tidak lupa, ucapan terima kasih juga disampaikan termasuk kepada tim Jurnal Esensi Hukum sehingga artikel ini untuk dapat diterbitkan sebagai pelengkap khasanah keilmuan di bidang hukum.

\section{Daftar Pustaka / Daftar Referensi}

\section{Buku}

Apeldoorn, L.J.V. (1982). Pengantar Ilmu Hukum, cetakan ke-19. Jakarta: Pradnya Paramita.

Asshiddiqie, J. (2014). Perihal Undang-Undang. Jakarta: PT RajaGrafindo. . (2016). Konstitusi Ekonomi. Jakarta: PT Kompas Media Nusantara.

Hadjon, P.M., dkk. (2015). Pengantar Hukum Administrasi Indonesia. Yogyakarta: Gadjah Mada University Press.

Haggard, T.R., \& David W.R.C. (1996). Legal Drafting in a Nutshell. Minnesota: West Publishing.

Ilmar, A. (2014). Hukum Tata Pemerintahan. Jakarta: Kencana.

Marbun, S.F., \& Moh. Mahfud M.D. (2011). Pokok-pokok Hukum Administrasi Negara.

Yogyakarta: Liberty.

Sudarto. (1990). Hukum Pidana I, cetakan ke II. Semarang: Yayasan Sudarto.

Sugianto, F. (2013). Economic Analysis of Law, Seri I. Jakarta: Kencana.

Soekanto, S. (2016). Faktor-faktor yang Mempengaruhi Penegakan Hukum. Jakarta: RajaGrafindo.

\section{Peraturan Perundang-Undangan}

Negara Republik Indonesia, Undang-Undang Dasar Negara Republik Indonesia Tahun 1945.

Negara Republik Indonesia, Undang-Undang Nomor 6 Tahun 1983 tentang Ketentuan Umum dan Tata Cara Perpajakan (Lembaran Negara Republik Indonesia Tahun 1983 Nomor 49, Tambahan Lembaran Negara Republik Indonesia Nomor 3262), sebagaimana telah beberapa kali diubah, terakhir dengan Undang-Undang Nomor 16 Tahun 2009 (Lembaran Negara Republik Indonesia Tahun 2009 Nomor 62, Tambahan Lembaran Negara Republik Indonesia Nomor 4999).

Negara Republik Indonesia, Undang-Undang Nomor 31 Tahun 2004 tentang Perikanan (Lembaran Negara Republik Indonesia Tahun 2004 Nomor 118, Tambahan 
Lembaran Negara Republik Indonesia Nomor 4433), sebagaimana telah diubah dengan Undang-Undang Nomor 45 Tahun 2009 (Lembaran Negara Republik Indonesia Tahun 2009 Nomor 160, Tambahan Lembaran Negara Republik Indonesia Nomor 5079).

Negara Republik Indonesia, Undang-Undang Nomor 32 Tahun 2009 tentang Perlindungan dan Pengelolaan Lingkungan Hidup (Lembaran Negara Republik Indonesia Tahun 2009 Nomor 140, Tambahan Lembaran Negara Republik Indonesia Nomor 5059).

Negara Republik Indonesia, Undang-Undang Nomor 12 Tahun 2011 tentang Pembentukan Peraturan Perundang-undangan (Lembaran Negara Republik Indonesia Tahun 2011 Nomor 82, Tambahan Lembaran Negara Republik Indonesia Nomor 5234).

\section{Jurnal}

Nasution, B.J. (2014). Upaya Penerapan Sanksi Administratif dan Perizinan Sebagai Pembatasan Terhadap Kebebasan Bertindak. Asy-Syir'ah, 48 (1).

Raharja, I.V. (2014). Penegakan Hukum Sanksi Administrasi Terhadap Pelanggaran Perizinan. Inovatif, VII (I).

\section{Putusan Pengadilan}

Putusan Pengadilan Tata Usaha Negara Jakarta Nomor 203/G/2015/PTUN-JKT, diucapkan pada sidang terbuka tanggal 23 Juni 2016.

Putusan Pengadilan Tata Usaha Negara Jakarta Nomor 204/G/2015/PTUN-JKT, diucapkan pada sidang terbuka tanggal 23 Juni 2016.

Putusan Pengadilan Tata Usaha Negara Jakarta Nomor 205/G/2015/PTUN-JKT, diucapkan pada sidang terbuka tanggal 23 Juni 2016.

Putusan Pengadilan Tata Usaha Negara Jakarta Nomor 211/G/2015/PTUN-JKT, diucapkan pada sidang terbuka tanggal 20 April 2016.

\section{Bahan Lain}

Yusuf, A.W. (2016). Sanksi Administrasi dalam Hukum Administrasi Negara. Seminar Kaidah Perumusan Sanksi Administratif dan Sanksi Pidana dalam UndangUndang. Jakarta: Pusat Perancangan Undang-Undang, Badan Keahlian DPR RI.

Simatupang, D.P.N. (2016). Penentuan Sanksi Administrasi dalam Undang-Undang. Seminar Kaidah Perumusan Sanksi Administratif dan Sanksi Pidana dalam Undang-Undang. Jakarta: Pusat Perancangan Undang-Undang, Badan Keahlian DPR RI.

Santosa, M.A.S.A. (2017). Kebijakan Pemberantasan Illegal, Unreported, and Unregulated Fishing. Kuliah Umum dan Orientasi Ke-UGM-an. Yogyakarta, 25 September 2017.

Marbun, S.F. (2017). Bahan Kuliah Hukum Administrasi Negara dan PTUN. Program Pascasarjana Ilmu Hukum, Fakultas Hukum Universitas Islam Indonesia. 